\title{
Infection Prevalence of Borrelia burgdorferi in Ticks Collected from Songbirds in Far-Western Canada
}

\author{
John D. Scott ${ }^{1}$, Lance A. Durden ${ }^{2}$, John F. Anderson ${ }^{3}$ \\ ${ }^{1}$ Research Division, Lyme Ontario, Fergus, Ontario, Canada \\ ${ }^{2}$ Department of Biology, Georgia Southern University, Statesboro, GA, USA \\ ${ }^{3}$ Department of Entomology and Center for Vector Ecology and Zoonotic Diseases, The Connecticut Agricultural \\ Experiment Station, New Haven, CT, USA \\ Email: jkscott@bserv.com
}

Received 18 April 2015; accepted 23 May 2015; published 28 May 2015

Copyright (C) 2015 by authors and Scientific Research Publishing Inc. This work is licensed under the Creative Commons Attribution International License (CC BY). http://creativecommons.org/licenses/by/4.0/

(c) (i) Open Access

\section{Abstract}

Worldwide, wild birds play a vital role in the dispersal of ticks that harbour tick-borne pathogens, including Borrelia burgdorferi, the Lyme disease bacterium. Using PCR testing, we found 124 (31\%) of 405 ticks (4 species), which were collected from 21 species of birds in far-western Canada, to be infected with $B$. burgdorferi. Transstadial transmission of $B$. burgdorferi occurred from larva to nymph, plus nymph to adult, in the avian coastal tick, Ixodes auritulus, collected from songbirds in British Columbia (B.C). Collectively, all 3 motile life stages (larva, nymph, adult) of this tick had an infection prevalence of $\mathbf{3 1 \%}$ for $B$. burgdorferi, which suggests vector competency. A Pacific Wren was highly infested with I. auritulus immatures, and 20 (44\%) of 45 ticks (2 nymphs, 43 larvae) were infected with $B$. burgdorferi. This heavy infestation shows the high potential to initiate a new population of ticks and to disseminate Lyme spirochetes. Epidemiologically, B. burgdorferi-infected I. auritulus larvae collected from the Spotted Towhee, Swainson's Thrush, Pacific Wren, and Fox Sparrow suggest that these avian hosts act as reservoirs for $B$. burgdorferi. In this study, the western blacklegged tick, Ixodes pacificus, and Ixodes spinipalpis played a limited role in the enzootic transmission cycle of $B$. burgdorferi along coastal B.C. We document the first record of $I$. spinipalpis on a bird in Alberta. Because songbirds widely disperse Lyme disease vector ticks, primary health providers and the general public must be vigilant that outdoors people may be bitten by $B$. burgdorferi-infected ticks throughout far-western Canada.

\section{Keywords}

Ticks, Ixodes auritulus, Ixodes pacificus, Ixodes spinipalpis, Lyme Disease, Borrelia burgdorferi, Songbird, Bird Parasitism, Infection Prevalence 


\section{Introduction}

Worldwide, Lyme disease (Lyme borreliosis) is present in more than 80 countries, and the causative agent infects a wide diversity of vertebrates, including wild birds. In the United States of America, this debilitating disease has been estimated to cost $\$ 1.3$ billion annually [1].

Passerine birds (order: Passeriformes), commonly called songbirds, are hosts for certain hard-bodied ticks (Ixodida: Ixodidae) that carry pathogenic microorganisms. These blood-sucking ectoparasites carry a wide group of tick-borne pathogens, including the Lyme disease bacterium, Borrelia burgdorferi sensu lato (s.l.) Johnson, Schmidt, Hyde, Steigerwalt \& Brenner (hence B. burgdorferi) [2]. Previously, tick researchers reported the avian coastal tick, Ixodes auritulus Newmann; the mouse tick, Ixodes muris Bishopp and Smith; the western blacklegged tick, Ixodes pacificus Cooley \& Kohls; and Ixodes spinipalpis Hadwen \& Nuttall, as ectoparasites of passerines in British Columbia [3] [4]. In Alberta, Scott et al. [4] [5] reported Ixodes scapularis Say, the primary vector of $B$. burgdorferi east of the Rocky Mountains, on migratory songbirds and, likewise, I. pacificus immatures on Neotropical migrants [3]. Of note, Gregson [6] reported I. auritulus, I. pacificus, and I. spinipalpis in far-western Canada and, of these, I. auritulus and I. spinipalpis were recorded on passerines.

Wild birds are capable of transporting ticks long distances during migratory flight. These tick-infested migrants are normally moving from winter grounds to breeding ranges and vice versa. Migratory birds carry attached ticks hundreds of kilometres within and between continents [3] [4] [7]-[11]. Similarly, both Neotropical passerines and seabirds can transport Lyme disease vector ticks during transhemispheric flight [12] [13]. Ultimately, certain rapid flyers can disperse replete ticks over wide biogeographical distribution ranges. Resident and migratory passerines can establish new foci of ticks and spirochetes [3]-[5] [14]-[16]; thus, exposing people and domestic animals that would otherwise not encounter spirochete-infected ticks. During breeding, nesting and fledging periods, wild birds serve as maintenance hosts for certain ticks [16] [17].

Ixodes auritulus, which is found exclusively on birds [18], is native along many seacoasts worldwide, including the Western Hemisphere, Antarctica, Australia, New Zealand, and islands south of Africa [19]-[21]. Even though $I$. auritulus does not bite humans, it parasitizes members of at least 8 bird orders globally [21], including Galliformes, Falconiformes, and Passeriformes in Canada [4] [22].

In North America, Ixodes muris parasitizes domestic and wildlife animals, such as mice, shrews, rats, and several species of birds [18]. Previously, all 3 motile life stages have been collected from passerines in several provinces across Canada [3] [4] [6].

Ixodes pacificus has a geographic range from southwestern Canada to northern Mexico (i.e., Baja California) [3] [18] [23]. In California, Castro and Wright [24] documented I. pacificus on 108 different species of vertebrates and, of these hosts, larvae and nymphs were on 38 bird species.

Ixodes spinipalpis is a nidicolous tick in semiarid regions, and has a host range from southwestern Canada to Texas [4] [18]. Vertebrate hosts include rodents [25] [26], lagomorphs [27], and passerine birds [4] [6]. In addition, I. spinipalpis has been reported parasitizing mammalian hosts in Alberta, but not previously on birds [6] [28] [29]. These tick collections in Alberta were made on the east face of the Rockies and near the southern fringe of the province bordering Montana.

The present study was designed to determine: 1) the infection prevalence of B. burgdorferi in bird-feeding ticks and 2) pinpoint passerine species that are most heavily involved in tick infestations and enzootic maintenance of Lyme disease spirochetes.

\section{Materials and Methods}

\subsection{Tick Collection}

Ticks were collected from wild-caught songbirds at various times of the year at 9 locations from Alberta and British Columbia, 2010-2012 (Figure 1). The majority of ticks were collected by bird banders using mist-nets, but ticks were also collected by wildlife rehabilitators from injured birds, such as automobile strikes and window strikes. Live ticks were put in round-bottom, $8.5 \mathrm{~mL}$ polypropylene tubes $(15.7 \times 75 \mathrm{~mm})$ with labels listing of background information. A 7-mm hole was drilled in the polyethylene, push caps (15.7 mm diameter) for ventilation. Tulle netting was inserted inside the cap to prevent ticks from escaping. Tubes with field-collected ticks were then placed in a self-sealing, double-zipper, plastic bag with a slightly moistened paper towel. Ticks were sent directly by express mail to the laboratory (JDS) for morphological identification. Taxonomic keys were 


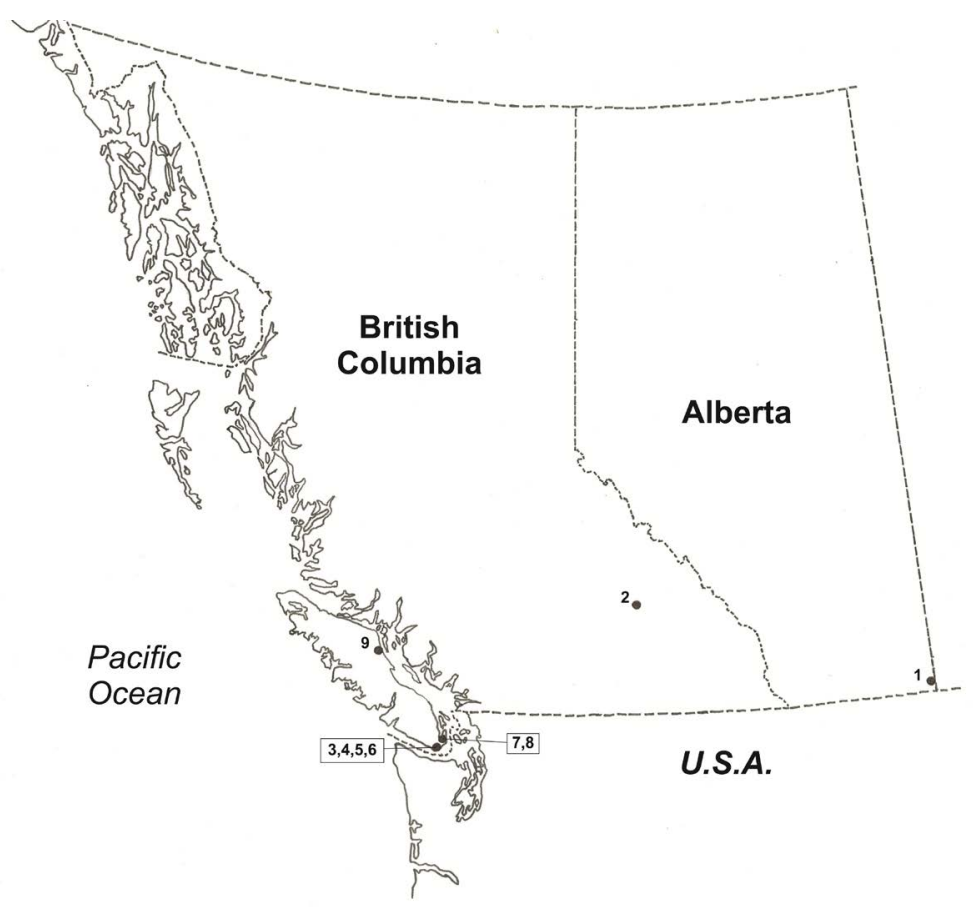

Figure 1. Map of Alberta and British Columbia showing tick collection sites: 1. Cypress Hills Interprovincial Park, Alberta, 49 34'31"N, 110 00'21"W; 2. Revelstoke, British Columbia, 5059'53"N, 118 11'44"W; 3. Peddar Bay, Vancouver Island, B.C. (Victoria), $48^{\circ} 20^{\prime} 58^{\prime \prime} \mathrm{N}, 123^{\circ} 34^{\prime} 40^{\prime \prime} \mathrm{W} ; 4$. Witty Lagoon, Metchosin, Vancouver Isl., B.C., 48 $23^{\prime} 2^{\prime \prime} \mathrm{N}, 1^{\prime 2} 3^{\circ} 30^{\prime} 58^{\prime \prime} \mathrm{W}$ (Victoria); 5. Metchosin, Vancouver Isl., B.C., 48²2'55"N, 12332'16"W (Victoria); 6. Rocky Point Bird Observatory, Rocky Point, Vancouver Island, B.C., 48 ${ }^{\circ} 19^{\prime} 42^{\prime \prime N}$, 123 34'18"W (Victoria); 7. Maltby Lake, Saanich Peninsula, Vancouver

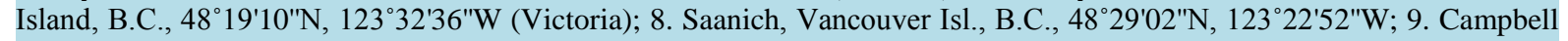
River, Vancouver Isl., B.C., 5001'28"N, 125'14'51"W. Mailing addresses are listed in parentheses.

also employed [18] [30]. Damaged and dead ticks were put directly in $2 \mathrm{~mL}$ micro tubes containing 94\% ethyl alcohol.

\subsection{Spirochete Detection}

Dead ticks were directly tested using DNA extraction and polymerase chain reaction (PCR) analysis, whereas live ticks were cultured in Barbour-Stoenner-Kelly (BSK) medium and, subsequently, underwent DNA extraction and PCR amplification. The detailed PCR protocol that we used, including primers, and its accuracy in detecting $B$. burgdorferi in live, dried, and alcohol preserved specimens, was thoroughly described by Persing et al. [31] [32] with in-house modifications [22]. With respect to culturing, B. burgdorferi spirochetes were isolated from 4 ticks.

\subsection{Voucher Specimens}

The I. spinipalpis specimen (10-5A7), which was collected from a White-crowned Sparrow at Cypress Hills Interprovincial Park, Alberta, was deposited in the Biodiversity Institute of Ontario (University of Guelph, Guelph, Ontario, Canada) with accession number BIO-12-120.

\section{Results}

A total of 405 Ixodes ticks consisting of 4 species were collected from 21 bird species by bird banders and wildlife rehabilitators in Alberta and British Columbia (B.C.), Canada (Table 1; Figure 1). Along the coast, $388 \mathrm{I}$. auritulus (37 females, 193 nymphs, 158 larvae) were collected from passerines. The earliest collection of $I$. auritulus was 17 February and the latest was 8 November. Of note, these I. auritulus collections indicate that this tick species has host-seeking activities year-round. In southwestern British Columbia, five I. pacificus (4 nymphs, 1 larva) were recorded. In Alberta and B.C., eleven I. spinipalpis (6 nymphs, 5 larvae) were detached. A single I. muris female was collected in southcentral B.C. 
Table 1. Detection of Borrelia burgdorferi in Ixodes ticks collected from wild-caught songbirds in far-western Canada, 2010-2012.

\begin{tabular}{|c|c|c|c|c|c|c|c|c|c|}
\hline \multicolumn{10}{|c|}{ No. of ticks positive/No. of ticks tested (\%) } \\
\hline & \multicolumn{3}{|c|}{ Ixodes auritulus } & \multirow{2}{*}{$\begin{array}{c}\text { I. muris } \\
\qquad \mathrm{F}\end{array}$} & \multicolumn{2}{|c|}{ I. pacificus } & \multicolumn{2}{|c|}{ I. spinipalpis } & \multirow[b]{2}{*}{$\begin{array}{l}\text { Infection prevalence } \\
(\%)\end{array}$} \\
\hline Bird species & $\mathrm{L}$ & $\mathrm{N}$ & $\mathrm{F}$ & & $\mathrm{L}$ & $\mathrm{N}$ & $\mathrm{L}$ & $\mathrm{N}$ & \\
\hline $\begin{array}{c}\text { Spotted Towhee } \\
\text { Pipilo maniculatus Swainson }\end{array}$ & $2 / 2$ & $6 / 16$ & $1 / 1$ & $0 / 0$ & $0 / 0$ & $0 / 3$ & $0 / 1$ & $1 / 1$ & $10 / 24(42)$ \\
\hline $\begin{array}{l}\text { Swainson's Thrush } \\
\text { Catharus ustulatus Nuttall }\end{array}$ & $1 / 2$ & $24 / 36$ & $1 / 8$ & $0 / 0$ & $0 / 0$ & $0 / 0$ & $0 / 0$ & $0 / 0$ & $26 / 46(57)$ \\
\hline $\begin{array}{c}\text { Song Sparrow } \\
\text { Melospiza melodia (Wilson) }\end{array}$ & $0 / 1$ & $9 / 29$ & $0 / 1$ & $0 / 0$ & $0 / 0$ & $0 / 0$ & $0 / 1$ & $0 / 4$ & $9 / 36(25)$ \\
\hline $\begin{array}{c}\text { House Wren } \\
\text { Troglodytes aedon Vieillot }\end{array}$ & $0 / 0$ & $0 / 0$ & $2 / 2$ & $0 / 0$ & $0 / 0$ & $0 / 1$ & $0 / 1$ & $0 / 0$ & $2 / 4(50)$ \\
\hline $\begin{array}{l}\text { American Robin } \\
\text { Turdus migratorius L. }\end{array}$ & $0 / 0$ & $0 / 0$ & $0 / 5$ & $0 / 0$ & $0 / 0$ & $0 / 0$ & $0 / 0$ & $0 / 0$ & $0 / 5(0)$ \\
\hline $\begin{array}{c}\text { Bewick's Wren } \\
\text { Thryomanes bewickii (Audubon) }\end{array}$ & $0 / 0$ & $1 / 2$ & $0 / 1$ & $0 / 0$ & $0 / 0$ & $0 / 0$ & $0 / 0$ & $1 / 1$ & $2 / 4(50)$ \\
\hline $\begin{array}{c}\text { Pacific Wren } \\
\text { Troglodytes pacificus S.F. Baird }\end{array}$ & $19 / 43$ & $1 / 3$ & $2 / 4$ & $0 / 0$ & $0 / 0$ & $0 / 0$ & $0 / 0$ & $0 / 0$ & $22 / 50(50)$ \\
\hline $\begin{array}{c}\text { Wilson’s Warbler } \\
\text { Wilsonia pusilla (Wilson) }\end{array}$ & $0 / 2$ & $1 / 2$ & $0 / 0$ & $0 / 0$ & $0 / 0$ & $0 / 0$ & $0 / 0$ & $0 / 0$ & $1 / 4(25)$ \\
\hline $\begin{array}{l}\text { Common Yellowthroat } \\
\text { Geothlypis trichas (L.) }\end{array}$ & $0 / 0$ & $0 / 4$ & $0 / 1$ & $0 / 1$ & $0 / 0$ & $0 / 0$ & $0 / 0$ & $0 / 0$ & $0 / 5(0)$ \\
\hline $\begin{array}{c}\text { Savannah Sparrow } \\
\text { Passerculus sandwichensis (Gmelin) }\end{array}$ & $0 / 0$ & $0 / 1$ & $0 / 0$ & $0 / 0$ & $0 / 0$ & $0 / 0$ & $0 / 0$ & $0 / 0$ & $0 / 1(0)$ \\
\hline $\begin{array}{c}\text { Lincoln’s Sparrow } \\
\text { Melospiza lincolnii (Audubon) }\end{array}$ & $0 / 0$ & $4 / 5$ & $0 / 0$ & $0 / 0$ & $0 / 0$ & $0 / 0$ & $0 / 0$ & $0 / 0$ & $4 / 5$ (80) \\
\hline $\begin{array}{c}\text { Fox Sparrow } \\
\text { Passerella iliaca (Merrem) }\end{array}$ & 23/97 & $19 / 82$ & $2 / 4$ & $0 / 0$ & $0 / 0$ & $0 / 0$ & $0 / 0$ & $0 / 0$ & 44/183 (24) \\
\hline $\begin{array}{l}\text { Golden-crowned Sparrow } \\
\text { Zonotrichia atricapilla (Gmelin) }\end{array}$ & $0 / 0$ & $0 / 0$ & $0 / 1$ & $0 / 0$ & $0 / 0$ & $0 / 0$ & $0 / 0$ & $0 / 0$ & $0 / 1(0)$ \\
\hline $\begin{array}{l}\text { Brown-headed Cowbird } \\
\text { Molothrus ater (Boddaert) }\end{array}$ & $0 / 0$ & $0 / 0$ & $0 / 1$ & $0 / 0$ & $0 / 0$ & $0 / 0$ & $0 / 0$ & $0 / 0$ & $0 / 1(0)$ \\
\hline $\begin{array}{c}\text { Puget Sound White-crowned Sparrow } \\
\text { Zonotrichia leucophrys } \\
\text { pugetensis (Forster) }\end{array}$ & $0 / 0$ & $0 / 2$ & $0 / 0$ & $0 / 0$ & $0 / 0$ & $0 / 0$ & $1 / 2$ & $0 / 0$ & $1 / 5(20)$ \\
\hline $\begin{array}{c}\text { Oregon Junco } \\
\text { Junco hyemalis oreganus (L.) }\end{array}$ & $0 / 0$ & $1 / 3$ & $1 / 2$ & $0 / 0$ & $0 / 0$ & $0 / 0$ & $0 / 0$ & $0 / 0$ & $2 / 5(40)$ \\
\hline $\begin{array}{c}\text { Hermit Thrush } \\
\text { Catharus guttatus (Pallas) }\end{array}$ & $0 / 11$ & $0 / 3$ & $1 / 1$ & $0 / 0$ & $0 / 0$ & $0 / 0$ & $0 / 0$ & $0 / 0$ & $1 / 15(7)$ \\
\hline $\begin{array}{l}\text { White-throated Sparrow } \\
\text { Zonotrichia albicollis (Gmelin) }\end{array}$ & $0 / 0$ & $0 / 3$ & $0 / 2$ & $0 / 0$ & $0 / 0$ & $0 / 0$ & $0 / 0$ & $0 / 0$ & $0 / 5(0)$ \\
\hline $\begin{array}{l}\text { Orange-crowned Warbler } \\
\text { Vermivora celata (Say) }\end{array}$ & $0 / 0$ & $0 / 0$ & $0 / 1$ & $0 / 0$ & $0 / 0$ & $0 / 0$ & $0 / 0$ & $0 / 0$ & $0 / 1(0)$ \\
\hline $\begin{array}{c}\text { Chipping Sparrow } \\
\text { Spizella passerina (Bechstein) }\end{array}$ & $0 / 0$ & $0 / 1$ & $0 / 1$ & $0 / 0$ & $0 / 1$ & $0 / 0$ & $0 / 0$ & $0 / 0$ & $0 / 3(0)$ \\
\hline $\begin{array}{l}\text { MacGillivray's Warbler } \\
\text { Oporornis tolmiei (Townsend) }\end{array}$ & $0 / 0$ & $0 / 1$ & $0 / 0$ & $0 / 0$ & $0 / 0$ & $0 / 0$ & $0 / 0$ & $0 / 0$ & $0 / 1(0)$ \\
\hline Totals & $45 / 158$ & $66 / 193$ & $10 / 37$ & $0 / 1$ & $0 / 1$ & $0 / 4$ & $1 / 5$ & $2 / 6$ & $124 / 405$ (31) \\
\hline
\end{tabular}

L, larva (e); N, nymph (s); F, female (s).

Using PCR amplification, 124 (31\%) of 405 tested ticks were infected with B. burgdorferi. As well, 121 (31\%) of 388 I. auritulus (females, nymphs, larvae) were infected. These numbers clearly show that wild birds are dispersing ticks and the human pathogen, B. burgdorferi, in the Canadian Far-West. 
New host records in Canada include: 1) I. auritulus (nymph; B. burgdorferi-positive) on a Bewick's Wren, 2) I. pacificus (larva; molted after 36 d) on an Orange-crowned Warbler, and 3) I. spinipalpis (larva; molted after $44 \mathrm{~d}$ ) on a Puget Sound White-crowned Sparrow. A fully engorged I. auritulus nymph was collected from a Fox Sparrow on 8 November 2012, and constitutes the latest date in the bird banding season that we have collected this tick species. DNA sequencing was not conducted on any of the four $B$. burgdorferi isolates.

\section{Discussion}

Our findings highlight four Ixodes species that are dispersed by passerine birds in far-western Canada. Along the West Coast, all 3 motile life stages of $I$. auritulus were well represented and the predominant tick species on residential and migratory songbirds. Notably, some of the passerines with attached B. burgdorferi-infected larvae are candidates for reservoir competency. In Alberta, we documented for the first time I. spinipalpis on birds east of the Rockies. Each of the 4 Ixodes species in our study is involved in the enzootic transmission cycle of $B$. burgdorferi.

\subsection{Ixodes spinipalpis on Songbirds in Alberta}

The collection of a fully engorged I. spinipalpis nymph from a White-crowned Sparrow, Zonotrichia leucophrys (Forster) at Cypress Hills Interprovincial Park, Elkwater Lake, Alberta on 15 May 2010 constitutes the first record of this tick species on an avian host in this province. The nymph molted to a female in $60 \mathrm{~d}$, and represents the northernmost reported recovery of I. spinipalpis on a songbird in North America.

In addition, 2 fully engorged I. spinipalpis larvae were collected from a House Wren, Troglodytes aedon (Viellot) on 9 June 2010 at the same location; these larvae molted to nymphs in $32 \mathrm{~d}$ and $33 \mathrm{~d}$, respectively. One of these ticks was tested for B. burgdorferi, and it was negative.

Previously, I. scapularis immatures were reported in Alberta [3] [5] and, likewise, I. pacificus nymphs were reported in this province [33]. There are at least 3 species of Lyme disease vector ticks in Alberta carried and dispersed by wild birds.

Also, I. spinipalpis immatures were previously collected from mammalian hosts on the east face of the Rocky Mountains and on the southern fringe of Alberta bordering Montana, USA [6] [28] [29].

\subsection{Transstadial Transmission of B. burgdorferi in I. auritulus}

The successful passage of viable $B$. burgdorferi during the larva-nymph and nymph-adult molts suggest vector competence of $I$. auritulus. In the present study, we document new reports of transstadial transmission of $B$. burgdorferi in I. auritulus (Table 2). Even though we experienced difficulty in culturing B. burgdorferi, we successfully obtained a live culture from a specimen that had molted from a nymph to an adult. We are aware of at least 4 genotypes/genospecies of B. burgdorferi in British Columbia [3], and each of these variant genotypes produced live cultures. Previously, vector competency for B. burgdorferi has been experimentally established for 12 tick species [34]. Scott et al. [4] provide initial evidence of transstadial transmission of B. burgdorferi in the larva-nymph molt of $I$. auritulus but not in the nymph-adult molt. Although I. auritulus does not bite humans, this tick species helps to maintain borrelial spirochetes in the enzootic transmission cycles along coastal British Columbia.

\subsection{Heavy Infestations of I. auritulus on Songbirds}

In this study, we recorded heavy infestations of $I$. auritulus on certain songbirds during October. Most notably, we recovered 45 I. auritulus (2 nymphs, 43 larvae) from a Pacific Wren on 11 October 2010 at Rocky Point, B.C. and, of these ticks, 20 (1 nymph, 19 larvae) were positive for B. burgdorferi. In addition, 42 I. auritulus (4 nymphs, 38 larvae) were collected from a Fox Sparrow on 7 October 2010 at the same location; 18 of these ticks (2 nymphs, 16 larvae) were positive for B. burgdorferi. Because larvae were infected with $B$. burgdorferi in both cases, these infestations strongly suggest that these passerines are reservoir-competent hosts. Based on the close proximity to the state of Washington, USA, migratory songbirds could act as cross-border carriers of Lyme disease vector ticks, especially during southward fall migration. Collectively, I. auritulus is one of at least 4 congeneric species of ticks parasitizing wild birds in B.C. Epidemiologically, these resident and migratory birds could easily initiate new Lyme disease foci. 
Table 2. Transstadial transmission of Borrelia burgdorferi in fully engorged Ixodes auritulus ticks collected from songbirds on Vancouver Island, British Columbia.

\begin{tabular}{|c|c|c|c|c|c|}
\hline Tick ID. No. & Bird species & Date ticks collected & $\begin{array}{c}\text { Life Stage } \\
\text { pre-molt post-molt }\end{array}$ & Days to molt & Presence of $B$. burgdorferi \\
\hline \multicolumn{6}{|c|}{ Larva-nymph molt } \\
\hline 12-5A126B & Fox Sparrow & 15 Oct 2012 & Larva-nymph & 57 & Amplicon \\
\hline 12-5A130A & Spotted Towhee & 17 Oct 2012 & Larva—nymph & 52 & Amplicon \\
\hline \multicolumn{6}{|c|}{ Nymph-adult molt } \\
\hline $10-5 \mathrm{~A} 46$ & Bewick’s Wren & 24 Aug 2012 & Nymph—female & 49 & Live culture \\
\hline 11-5A62B & Lincoln’sSparrow & 11 Sep 2012 & Nymph—female & 47 & Amplicon \\
\hline 11-5A62C & same host & 11 Sep 2012 & Nymph—female & 47 & Amplicon \\
\hline 11-5A62D & same host & 11 Sep 2012 & Nymph—male & 43 & Amplicon \\
\hline $11-5 A 64$ & Swainson's Thrush & 14 Sep 2012 & Nymph—male & 48 & Amplicon \\
\hline $11-5 \mathrm{~A} 70 \mathrm{~A}$ & Fox Sparrow & 06 Oct 2012 & Nymph—male & 54 & Amplicon \\
\hline 11-5A70B & same host & 06 Oct 2012 & Nymph—male & 53 & Amplicon \\
\hline 12-5A82 & Swainson's Thrush & 11 Sep 2012 & Nymph—female & 55 & Amplicon \\
\hline 12-5A142 & Fox Sparrow & 08 Nov 2012 & Nymph—male & 43 & Amplicon \\
\hline
\end{tabular}

High tick infestations can occur when ground-foraging songbirds transect a microhabitat where gravid females lay their eggs. Wild birds eat ticks [8] [35]. These avifauna can be highly parasitized by newly hatched larvae while the bird eats the spent female. Of ecological significance, new larvae begin questing within a few days after the gravid female dies. This phenomenon can aid the success of larvae finding a host quickly. The dead female tick has a fat morsel in the posterior section of the idiosoma that provides a nutritious energy source for wild birds and small mammals.

In addition, because I. auritulus only parasitizes birds, the presence of Lyme disease spirochetes in all 3 life stages of $I$. auritulus indicates that a large mammal, such as a Sitka black-tailed deer, Odocoileus hemionus sitkensis (Rafinesque), is not required to perpetuate B. burgdorferi in this enzootic transmission cycle. In essence, I. auritulus is an exemplar of a single tick species that can perpetuate $B$. burgdorferi.

Our findings are consistent with other tick studies that show that songbirds have the capability to initiate new tick populations in distant locations [14]-[16]. The circumglobal distribution of I. auritulus highly supports the fact that wild birds can initiate new tick populations in both the Northern and Southern Hemispheres [12] [19] [21].

\subsection{Seasonal Occurrence of I. pacificus and Is spinipalpis}

The relative number of I. pacificus and I. spinipalpis immatures was low because our sampling effort was mainly conducted during the post-fledging and autumn migration (mid-August to early November). In the western coastal bioregion, the peak questing activity for I. pacificus larvae is mid-summer, whereas, for nymphs, it is during the period of mid-April to mid-June. For I. spinipalpis immatures, larvae are active from April to September, while nymphs have host-seeking activity mainly from April to October [27] [36]. We were unable to get good representation of I. pacificus and I. spinipalpis immatures because there were no bird banding activities during the spring and early summer.

\subsection{Absence of B. burgdorferi in I. pacificus Immatures}

The lack of B. burgdorferi infection in larval and nymphal I. pacificus in this study could be due to a number of ecological factors. The absence of B. burgdorferi in I. pacificus larvae substantiates the fact that this tick species does not exhibit transovarial transmission, and does not support the transfer of B. burgdorferi from gravid fe- 
males to larval offspring and, therefore, unfed larvae are typically devoid of spirochetal infection [37]. The non-infected I. pacificus nymphs indicate that the host birds were non-spirochetemic. As larvae, these I. pacificus immatures may have fed on spirochete-free hosts, such as the northern alligator lizard, Elgaria coerulea principis Baird, which is indigenous in the area. The blood of the western fence lizard, Sceloporous occidentialis Baird \& Girard, is noted for having a borreliacidal effect on I. pacificus immatures; a protein in its blood kills B. burgdorferi [38]. Since northern alligator lizards may also have a zooprophylactic effect on Lyme disease spirochetes in I. pacificus immatures, we suggest that a decrease in B. burgdorferi infection prevalence would be anticipated throughout the southwestern British Columbia region.

\subsection{Ixodes muris on Songbirds}

A single I. muris female was collected from a Common Yellowthroat, Geothlypis trichas (L.), on 11 August 2010 at Revelstoke, B.C., and it tested negative for B. burgdorferi. Previously, I. muris specimens were collected from passerines in British Columbia and, in 2008 [4], another female was collected from a different Common Yellowthroat at this same locality (Figure 2). Scott et al. [3] documented a B. burgdorferi-infected I. muris, which was collected from a White-throated Sparrow, Zonotrichia albicollis (Gmelin) at Amherst, Nova Scotia. Based on experimental studies with deer mice, Peromyscus maniculatus Wagner, which are indigenous across Canada, Dolan et al. [39] found that I. muris has vector competence for B. burgdorferi. Not only does I. muris exhibit vector competence, but this tick species also may have the potential to transmit Lyme disease spirochetes to various vertebrate hosts, including wild birds, dogs, cats, and humans (Scott, J.D., unpublished data).

\subsection{Songbirds as Reservoirs of $B$, burgdorferi}

The presence of B. burgdorferi in larval ticks collected from songbirds exemplifies the fact that certain birds are reservoirs for spirochetes. Using uninfected xenodiagnostic larvae, Richter et al. [40] demonstrated that the American Robin, Turdus migratorius L. is a competent reservoir for B. burgdorferi. In our study, several B. burgdorferi-infected I. auritulus larvae were collected from 4 bird species, namely, Fox Sparrow, Pacific Wren, Spotted Towhee, and Swainson's Thrush. As well, a B. burgdorferi-positive I. spinipalpis larva was collected from a Puget Sound White-crowned Sparrow. Based on our study and previous studies, certain birds demonstrate reservoir competence: Swainson's Thrush [3] [4] [41]-[43] and; likewise, Fox Sparrow [33]. In fact, the latter bird parasitism is the first documentation of a B. burgdorferi-infected larva on a bird in far-western North America. Because these $B$. burgdorferi-infected larvae had not taken a previous blood meal, we suggest that these passerines are valid candidates for reservoir competency. Not only does I. pacificus bite and transmit B. burgdorferi to humans [44], I. spinipalpis also bites humans [25] [45] and, as a Lyme disease vector tick, it could trans-

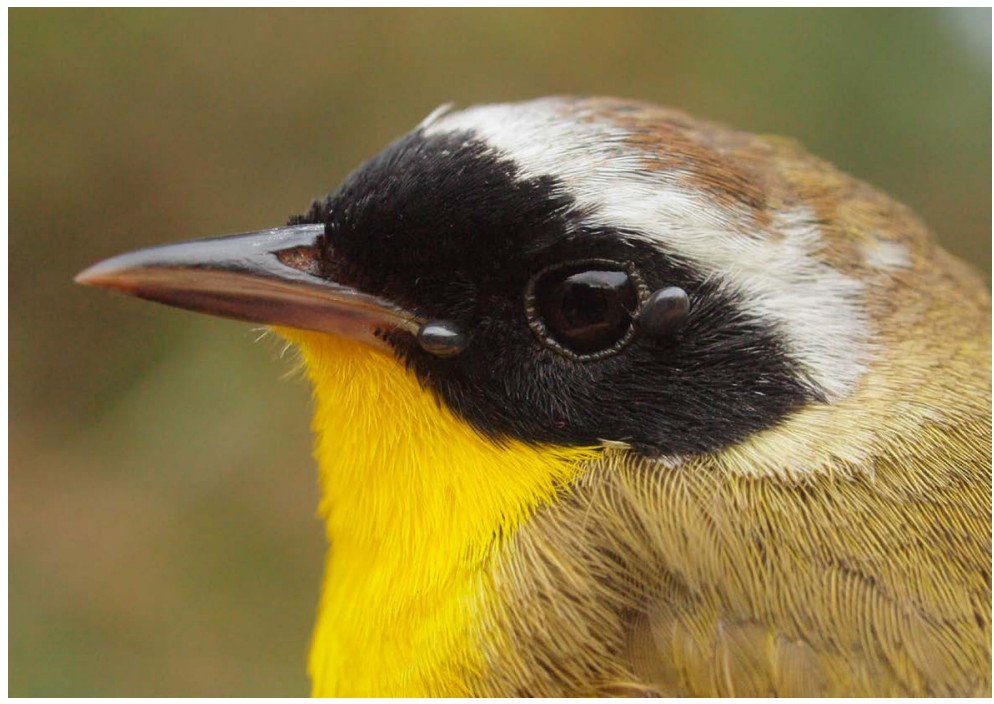

Figure 2. A male Common Yellowthroat parasitized by nymphal Ixodes ticks. Photo credit: Simon Duval. 
mit borreliae to humans.

Across Canada, songbirds play a significant role in the epidemiology of Lyme disease. In central and eastern Canada, Scott and Durden [46] report that 35\% of the Ixodes scapularis nymphs are infected with B. burgdorferi. On the West Coast, our Canadian study shows that $31 \%$ of I. auritulus ticks are infected with B. burgdorferi. Pointedly, many songbirds-transported ticks perpetuate the spread of Lyme disease.

In conclusion, resident and migratory songbirds are disseminators of borreliae. The present study provides additional evidence to show that all 3 motile stages of $I$. auritulus play a vital role in maintaining $B$. burgdorferi in the environment along the Pacific Coast. When B. burgdorferi-infected I. auritulus larvae and nymphs transmit spirochetes to Canadian songbirds, these avian hosts can transmit spirochetal infection to I. muris, I. pacificus and I. spinipalpis, which could act as bridge vectors and later bite humans. Passerines have the ability to quickly and easily move ticks and tick-associated pathogens long distances to new foci and, at the same time, act as reservoirs of B. burgdorferi. Most significantly, cohabitation of I. auritulus, I. muris, I. pacificus, and I. spinipalpis increase the public health risk of contracting Lyme disease along Canada's Pacific Coast.

\section{Acknowledgements}

We thank the following bird banders for collecting ticks from songbirds: Yousif Attia, Emily Barnewall, Troy Blondin, Christina Carrieres, Marianne Dawson, Louise Dykslag, Jessie Fanucchi, Andrea Follet, Vanessa Garland, Christina Lam, Susanne Maidment, Ann Nightingale, Michal Pavlik, Brian Pomfret, Amélia Rousseau, Rick Schortinghuis, and Acacio Spencer-Hills. We are indebted to Elizabeth A. Alves for technical assistance and, for computer graphics, John Ward and Ashton Ropp. For financial support, we thank Lyme Ontario and the Canadian Lyme Disease Foundation.

\section{References}

[1] Adrion, E.R., Aucott, J., Lemke, K.W. and Weiner, J.P. (2015) Health Care Costs, Utilization and Patterns of Health Care Costs Following Lyme Disease. PLoS One, 10. http://dx.doi.org/10.1371/journal.pone.0116767

[2] Burgdorfer, W., Barbour, A.G., Hayes, S.F., Benach, J.L., Grunwaldt, E. and Davis, J.P. (1982) Lyme Disease-A Tick-Borne Spirochetosis? Science, 216, 1317-1319. http://dx.doi.org/10.1126/science.7043737

[3] Scott, J.D., Lee, M.-K., Fernando, K., Durden, L.A., Jorgensen, D.R., Mak, S. and Morshed, M.G. (2010) Detection of Lyme Disease Spirochete, Borrelia burgdorferi Sensu Lato, including Three Novel Genotypes in Ticks (Acari: Ixodidae) Collected from Songbirds (Passeriformes) across Canada. Journal of Vector Ecology, 35, 124-139. http://dx.doi.org/10.1111/j.1948-7134.2010.00068.x

[4] Scott, J.D., Anderson, J.F. and Durden, L.A. (2012) Widespread Dispersal of Borrelia burgdorferi-Infected Ticks Collected from Songbirds across Canada. Journal of Parasitology, 98, 49-59. http://dx.doi.org/10.1645/GE-2874.1

[5] Scott, J.D., Fernando, K., Banerjee, S.N., Durden, L.A., Bryne, S.K., Banerjee, M., Mann, R.B. and Morshed, M.G. (2001) Birds Disperse Ixodid (Acari: Ixodidae) and Borrelia burgdorferi-Infected Ticks in Canada. Journal of Medical Entomology, 38, 493-500. http://dx.doi.org/10.1603/0022-2585-38.4.493

[6] Gregson, J.D. (1956) The Ixodoidea of Canada. Publication 930. Science Service, Entomology Divison, Canada Department of Agriculture, 92 p. http://dx.doi.org/10.5962/bhl.title.58947

[7] Hoogstraal, H. and Kaiser, M.N. (1961) Ticks from European-Asiatic Birds Migrating through Egypt into Africa. Science, 133, 277-278. http://dx.doi.org/10.1126/science.133.3448.277

[8] Ogden, N.H., Lindsay, R.L., Hanincová, K., Barker, I.K., Bigras-Poulin, M., Charron, D.F., Heagy, A., Francis, C.M., O’Callaghan, C.J., Schwartz, I. and Thompson, R.A. (2008) Role of Migratory Birds in Introduction and Range Expansion of I. scapularis Ticks and of Borrelia burgdorferi and Anaplasma phagocytophilum in Canada. Applied and Environmental Microbiology, 74, 1780-1790. http://dx.doi.org/10.1128/AEM.01982-07 (2008). Erratum: Applied and Environmental Microbiology, 74, 3919.

[9] Stutchbury, B.J.M., Tarof, S.A., Done, T., Gow, E., Kramer, P.M., Tautin, J., Fox, J.W. and Afanasyev, V. (2009) Tracking Long-Distance Songbird Migration by Using Geolocators. Science, 323, 896. http://dx.doi.org/10.1126/science.1166664

[10] Scott, J.D. and Durden, L.A. (2015) Songbird-Transported Tick Ixodes minor (Ixodida: Ixodidae) Discovered in Canada. Canadian Entomologist, 147, 46-50. http://dx.doi.org/10.4039/tce.2014.34

[11] Scott, J.D. and Durden, L.A. (2015) First Record of Amblyomma rotundatum Tick (Acari: Ixodidae) Parasitizing a Bird Collected in Canada. Systematic and Applied Acarology, 20, 151-161. http://dx.doi.org/10.11158/saa.20.2.1

[12] Olsén, B., Duffy, D.C., Jaenson, T.G.T., Glyffe, Å., Bonnedahl, J. and Bergström, S. (1995) Transhemispheric Ex- 
change of Lyme Disease Spirochetes by Seabirds. Journal of Clinical Microbiology, 33, 3270-3274.

[13] Scott, J.D. (2015) Birds Widely Disperse Pathogen-Infected Ticks. In: Mahala, G., Ed., Seabirds and Songbirds: Habitat Preferences, Conservation and Migratory Behaviour, Nova Science, New York, 1-22.

[14] Anderson, J.F. and Magnarelli, L.A. (1984) Avian and Mammalian Hosts for Spirochete-Infected Ticks and Insects in a Lyme Disease Focus in Connecticut. Yale Journal of Biology and Medicine, 57, 627-641.

[15] Anderson, J.F., Magnarelli, L.A. and Stafford III, K.C. (1990) Bird-Feeding Ticks Transstadially Transmit Borrelia burgdorferi That Infect Syrian Hamsters. Journal of Wildlife Diseases, 26, 1-10. http://dx.doi.org/10.7589/0090-3558-26.1.1

[16] Scott, J.D., Scott, C.M. and Anderson, J.F. (2014) The Establishment of a Blacklegged Tick Population by Migratory Songbirds in Ontario, Canada. Journal of Veterinary Science \& Medicine, 2, 5.

[17] Anderson, J.F. and Magnarelli, L.A. (1993) Epizootiology of Lyme Disease-Causing Borreliae. Clinics in Dermatology, 11, 339-351. http://dx.doi.org/10.1016/0738-081X(93)90088-T

[18] Durden, L.A. and Keirans, J.E. (1996) Nymphs of the Genus Ixodes (Acari: Ixodidae) of the United States: Taxonomy, Identification Key, Distribution, Hosts, and Medical/Veterinary Importance. Monographs, Thomas Say Publications in Entomology, Entomological Society of America, Lanham, MD.

[19] Robbins, R.G., Sorkin, L.N. and Vuilleumier, F. (2001) First Report of Ixodes auritulus Neumann (Acari: Ixodida: Ixodidae) from the Blackish Cinclodes, Cinclodes antarcticus (Garnot) (Aves: Passeriformes: Furnariidae), with Additional Records of Parasitism of Cinclodes spp. by This Tick Species. Proceedings of the Entomological Society of Washington, 103, 265-268. http://biostor.org/reference/57080

[20] Guglielmone, A.A., Estrada-Peña, A., Keirans, J.E. and Robbins, R.G. (2003) Ticks (Acari: Ixodidae) of the Neotropial Zoogeographic Region. International Consortium on Ticks and Tick-Borne Diseases, Atalanta, Houten, The Netherlands, $173 \mathrm{p}$.

[21] González-Acuña, D., Venzal, J.M., Keirans, J.E., Robbins, R.G., Ippi, S. and Guglielmone, A.A. (2005) New Host and Locality Records for the Ixodes auritulus (Arari: Ixodidae) Species Group, with a Review of Host Relationships and Distribution in the Neotropical Zoogeographic Region. Experimental and Applied Acarology, 37, 147-156. http://dx.doi.org/10.1007/s10493-005-8434-y

[22] Scott, J.D., Anderson, J.F. and Durden, L.A. (2013) First Detection of Lyme Disease Spirochete Borrelia burgdorferi in Ticks Collected from a Raptor in Canada. Journal of Veterinary Science and Medical Diagnosis, 2, 4. http://dx.doi.org/10.4172/2325-9590.1000123

[23] Banerjee, S.N., Banerjee, M., Smith, J.A. and Fernando, K. (1994) Lyme Disease in British Columbia—An Update. Proceedings of the VII Annual Lyme Disease Foundation International Conference, Stamford, 19-23 May 1994, 88 p.

[24] Castro, M.B. and Wright, S.A. (2007) Vertebrate Hosts of Ixodes pacificus (Acari: Ixodidae) in California. Journal of Vector Ecology, 32, 140-149. http://dx.doi.org/10.3376/1081-1710(2007)32[140:VHOIPA]2.0.CO;2

[25] Dolan, M.C., Maupin, G.O., Panelia, N.A., Golde, W.T. and Piesman, J. (1997) Vector Competence of Ixodes scapularis, I. spinipalpis, and Dermacentor andersoni (Acari: Ixodidae) in Transmitting Borrelia burgdorferi, the Etiologic Agent of Lyme Disease. Journal of Medical Entomology, 34, 128-135. http://dx.doi.org/10.1093/jmedent/34.2.128

[26] Eisen, L., Dolan, M.C., Piesman, J. and Lane, R.S. (2003) Vector Competence of Ixodes pacificus and I. spinipalpis (Acari: Ixodidae), and Reservoir Competence of Dusky-Footed Woodrat (Neotoma fuscipes) and the Deer Mouse (Peromyscus maniculatus), for Borrelia bissettii. Journal of Medical Entomology, 40, 311-320. http://dx.doi.org/10.1603/0022-2585-40.3.311

[27] Allfred, D.M., Beck, D.E. and White, L.D. (1960) Ticks of the Genus Ixodes in Utah. Brigham Young University Science Bulletin, Biological Series, 1, 1-42. http://ojs.lib.byu.edu/spc/index.php/BYUSciBullBioS/article/viewFile/30590/29072

[28] Brown, J.H. and Kohls, G.M. (1950) The Ticks of Alberta with Special Reference to Distribution. Canadian Journal of Research, 28, 197-205. http://dx.doi.org/10.1139/cjr50d-014

[29] Shemanchuk, J.A. and Kiceniuk, J.W. (1970) Ixodes spinipalpis Hadwen and Nuttall (Ixodidae) from Southern Alberta. Canadian Journal of Zoology, 48, 1142-1143. http://dx.doi.org/10.1139/z70-201

[30] Clifford, C.M., Anastos, G. and Elbl, A. (1961) The Larval Ixodid Ticks of the Eastern United States. Miscellaneous Publications of the Entomological Society of America, 2, 213-237. http://www.afpmb.org/sites/default/files/pubs/techguides/tg26/References/179579.pdf

[31] Persing, D.H., Telford III, S.R., Spielman, A. and Barthold, S.W. (1990) Detection of Borrelia burgdorferi Infection in Ixodes dammini Ticks with the Polymerase Chain Reaction. Journal of Clinical Microbiology, 28, 566-572. www.ncbi.nlm.nih.gov/pubmed/1969867

[32] Persing, D.H., Telford III, S.R., Rys, P.N., Dodge, D.E., White, T.J., Malawista, S.E. and Spielman, A. (1990) Detec- 
tion of Borrelia burgdorferi DNA in Museum Specimens of Ixodes dammini Ticks. Science, 249, 1420-1423. http://www.ncbi.nlm.nih.gov/pubmed/2402635 http://dx.doi.org/10.1126/science.2402635

[33] Morshed, M.G., Scott, J.D., Fernando, K., Beati, L., Mazerolle, D.F., Geddes, G. and Durden, L.A. (2005) Migratory Songbirds Disperse Ticks across Canada, and First Isolation of the Lyme Disease Spirochete, Borrelia burgdorferi, from the Avian Tick, Ixodes auritulus. Journal of Parasitology, 91, 780-790. http://dx.doi.org/10.1645/GE-3437.1

[34] Eisen, L. and Lane, R.S. (2002) Vectors of Borrelia burgdorferi Sensu Lato. In: Gray, J., Kahl, O., Lane, R.S. and Stanek, G., Eds., Lyme Borreliosis: Biology, Epidemiology and Control, CABI Publishing, New York, 91-115. http://dx.doi.org/10.1079/9780851996325.0091

[35] Milne, A. (1950) The Ecology of the European Sheep Tick, Ixodes ricinus L. Microhabitat of the Adult Tick. Parasitology, 40, 14-34. http://dx.doi.org/10.1017/S0031182000017820

[36] Burkot, T.R., Maupin, G.O., Schneider, B.S., DeNatale, C., Happ, C.M., Rutherford, J.S. and Zeidner, N.S. (2001) Use of a Sentinel Host System to Study the Questing Behaviour of Ixodes spinipalpis and Its Role in the Transmission of Borrelia bissetti, Human Granulocytic Ehrlichiosis, and Babesia microti. American Journal of Medicine and Hygiene, 65, 293-299. http://www.ncbi.nlm.nih.gov/pubmed/11693872

[37] Schoeler, G.B. and Lane, R.S. (1993) Efficiency of Transovarial Transmission of the Lyme Disease Spirochete, Borrelia burgdorferi, in the Western Blacklegged Tick, Ixodes pacificus (Acari: Ixodidae). Journal of Medical Entomology, 30, 80-86. http://www.ncbi.nlm.nih.gov/pubmed/8433348 http://dx.doi.org/10.1093/jmedent/30.1.80

[38] Lane, R.S. and Quistad, G.B. (1998) Borreliacidal Factor in the Blood of the Western Fence Lizard (Sceloporous occidentalis). Journal of Parasitology, 84, 29-34. http://www.jstor.org/stable/3284524 http://dx.doi.org/10.2307/3284524

[39] Dolan, M.C., Lacombe, E.H. and Piesman, J. (2000) Vector Competence of Ixodes muris (Acari: Ixodidae) for Borrelia burgdorferi. Journal of Medical Entomology, 37, 766-768. http://www.ncbi.nlm.nih.gov/pubmed/11004792 http://dx.doi.org/10.1603/0022-2585-37.5.766

[40] Richter, D., Spielman, A., Komar, N. and Matuschka, F.-R. (2000) Competence of American Robins as Reservoir Hosts for Lyme Disease Spirochetes. Emerging Infectious Diseases, 6, 133-138. http://dx.doi.org/10.3201/eid0602.000205

[41] Stafford III, K.C., Bladen, V.C. and Magnarelli, L.A. (1995) Ticks (Acari: Ixodidae) Infesting Wild Birds (Aves) and White-Footed Mice in Lyme, CT. Journal of Medical Entomology, 32, 453-466. http://www.ncbi.nlm.nih.gov/pubmed/7650706 http://dx.doi.org/10.1093/jmedent/32.4.453

[42] Durden, L.A., Oliver Jr., J.H. and Kinsey, A.A. (2001) Ticks (Acari: Ixodidae) and Spirochetes (Spirochaetaceae: Spirochaetales) Recovered from Birds on a Georgia Barrier Island. Journal Medical Entomology, 38, 231-236. http://dx.doi.org/10.1603/0022-2585-38.2.231

[43] Hamer, S.A., Goldberg, T.L., Kitron, U.D., Brawn, J.D., Anderson, T.K., Loss, S.R., Walker, E.D. and Hamer, G.L. (2012) Wild Birds and Urban Ecology of Ticks and Tick-Borne Pathogens, Chicago, Illinois, USA, 2005-2010. Emerging Infectious Diseases, 18, 1589-1595. http://dx.doi.org/10.3201/eid1810.120511

[44] Burgdorfer, W., Lane, R.S., Barbour, A.G., Gresbrink, R.A. and Anderson, J.R. (1985) The Western Black-Legged Tick, Ixodes pacificus: A Vector of Borrelia burgdorferi. American Journal of Tropical Medicine and Hygiene, 34, 925-930. http://www.ncbi.nlm.nih.gov/pubmed/3898886

[45] Eisen, L., Eisen, R.J. and Lane, R.S. (2006) Geographic Distribution Patterns and Habitat Suitability Models for Presence of Host-Seeking Ixodid Ticks in Dense Woodlands of Mendocino County, California. Journal of Medical Entomology, 43, 415-427. http://jme.oxfordjournals.org/content/jmedent/43/2/415.full.pdf

[46] Scott, J.D. and Durden, L.A. (2015) New Records of the Lyme Disease Bacterium in Ticks Collected from Songbirds in Central and Eastern Canada. International Journal of Acarology, 41, 241-249. http://dx.doi.org/10.1080/01647954.2015.1038301 